\title{
LAYANAN HOME VISIT PENDIDIKAN ANAK USIA DINI BAGI ANAK KURANG SEJAHTERA
}

\author{
Elis Komalasari \\ Program Studi Pendidikan Anak Usia Dini, Jurusan Tarbiyah, STAIN Batusangkar \\ Korespondensi: Jl. Sudirman No. 137, Kuburajo, Lima Kaum, Batusangkar, Sumatera Barat \\ e-mail: elis.dachlan@gmail.com
}

\begin{abstract}
Early childhood home visiting program to be one of the important components in the system of early childhood education in several countries. In some states in American, these countries have proved the success of early childhood home visiting services program, it can improving health and development in less prosperous families. Early childhood home visiting program is an alternative service in early childhood education which aims to improve access to services in early childhood intervention and meet the needs of early childhood living in conditions of risk and less prosperous families. Based on research, this service can build social capital and encourage the implementation of policies at the national level aimed at the welfare of children.In the practical implementation, early childhood home visiting program involved professionals in education, developmentalis and social workers to provide services to families who have young children and live below the poverty. The services providing education and parental guidance, the practice of home - based play for children, health and child development information, as well as services involving the surrounding community.This paper will (1) Discuss the success of implementation of early childhood home visit program in some countries, (2) examines how the practices of early childhood home visit program in promoting growth and development early childhood in less prosperous families, (3) analyze the mapping of early childhood home visit program in Indonesia to improve early childhood education participation rates in children and families less prosperous.
\end{abstract}

Kata kunci: home visiting program, early childhood education, children at risk

\section{PENDAHULUAN}

U sia dini merupakan masa kritis dalam perkembangan perilaku, sosial, kognitif dan fisik motorik. Beragam pengalaman yang diterima anak ketika masa usia dini akan memberikan pengaruh terhadap perkembangan otak dan menjadi dasar bagi keberhasilan sekolah dan kehidupan di masa yang akan datang.

Mendukung pernyataan di atas, Mary Eming Young (2002) dalam tulis- annya Ensuring a Fair Start for All Children mengungkapkan bahwa masa usia dini adalah masa yang rentan dan penuh peluang. Perubahan yang cepat dan dramatis dalam perkembangan mental dan fisik terjadi pada usia tiga tahun pertama kehidupan manusia. Selain itu, pengalaman yang diperoleh pada usia dini dapat membentuk perkembangan individu dan dapat memberikan suatu kesempatan unik untuk mengubah kehidupan seluruh anak. Pentingnya masa usia dini dalam memberikan pengalaman 
yang bermakna dalam kehidupan anak memerlukan dukungan dari orangtua dan lingkungan. Orangtua harus memberikan pengasuhan dan pendidikan yang baik pada anak, hal tersebut dapat berupa pemberian stimulasi yang tepat, nutrisi yang baik, kasih sayang dan lingkungan yang aman.

Untuk mewujudkan hal tersebut diperlukan peran yang berfokus pada keluarga. Peran keluarga menjadi hal yang penting dikarenakan pendidikan kedua orangtua dan praktek pengasuhan di rumah dapat menghasilkan perkembangan anak yang lebih baik, bahkan untuk anak-anak yang tidak berpartisipasi dalam program pendidikan anak usia dini. (Laporan awal proyek PPAUD Bank Dunia, 2012). Namun, pada umumnya kesadaran orang tua untuk meningkatkan fungsi dan peran keluarga dalam pengasuhan anak masih rendah, banyak orangtua yang beranggapan bahwa mengasuh anak berlangsung secara alami dan tidak perlu dipelajari. Adanya keterbatasan pengetahuan dan pengalaman orang tua dalam membangun lingkungan pengasuhan yang kondusif untuk mengoptimalkan periode emas anak ini.

Selain itu, selama ini banyak orangtua yang memiliki kesulitan dalam memberikan lingkungan yang memadai bagi kebutuhan intelektual anak. Ramey (Santrock, 1995) berpendapat bahwa sekali kesulitan tersebut menjadi bagian yang berulang dari sistem keluarga, upaya perubahan anak kemungkinan akan menjadi lebih sulit dan mahal. Intervensi awal dalam sistem keluarga diarahkan untuk mengubah pemfungsian yang adaptif dan tanggap sehingga pengaruh negatif yang permanen dapat diperkecil. Kondisi di atas menjadi sebuah permasalahan dan sekaligus tantangan untuk meningkatkan dukungan para orangtua dalam pengembangan anak usia dini.
Beragam penelitian dan program pendidikan anak usia dini telah dilakukan oleh beberapa ahli, salah satunya oleh Kimberly S. Howard dan Jeanne Brooks-Gunn (2009) yang mengembangkan program home visit untuk memberikan layanan pada anak-anak kurang sejahtera. Dari program tersebut terungkap bahwa program home visit tidak hanya menggunakan pendekatan teoritis, namun juga dapat menggunakan pendekatan praktis. Program ini melayani berbagai tingkatan usia anak, status keluarga, berbagai layanan yang ditawarkan, intensitas kunjungan rumah, dan isi dari kurikulum yang digunakan.

Program home visit diyakini akan memberikan dampak positif pada keluarga dan mengubah praktik pengasuhan orangtua yang terukur baik dalam hal pemberian stimulasi dan perawatan fisik anak. Selain, itu program home visit dapat memberikan manfaat jangka panjang untuk perkembangan anak, orang tua yang melaksanakan program home visit mendapatkan pengetahuan dan keterampilan terkait dengan praktik pengasuhan, pendidikan dan perawatan, sehingga orang tua dapat mengoptimalkan seluruh aspek perkembangan (sosial-emosional, kognitif-bahasa, dan fisik-motorik) anak yang akan menjadi landasandalam kehidupan anak di masa yang akan datang.

Program home visit telah banyak dilakukan untuk memfasilitasi keluarga terutama pada keluarga kurang mampu dalam meningkatkan pemahaman mereka mengenai perkembangan dan kebutuhan anak. Dengan mengacu pada beragam manfaat dari program layanan home visit yang telah diteliti dan dilakukan oleh para ahli, serta berdasarkan permasalahan yang dialami oleh anakanak usia dini yang hidup dalam kondisi beresiko pada keluarga kurang sejahtera sehingga menyebabkan angka partisipasi yang rendah dalam pendidikan anak usia dini, maka tulisan ini akanmengkaji secara lebih jauh mengenai pelaksanaan 
program home visit PAUD pada berbagai negara dan bagaimana peluang dan tantangan penyelenggaraannya di wilayah di Indonesia yang memiliki tingkat kerentanan cukup tinggi dalam hal tingkat partisipasi pendidikan dan kesejateraan anak pada keluarga kurang sejahtera.

\section{LAYANAN HOME VISIT PAUD}

Selama beberapa tahun terakhir, program home visit PAUD telah menjadi perbincangan dan melahirkan kontroversi dalam hal efektifitas program. Korfmacher, dkk (2008) mengungkapkan bahwa makna "home visiting" bisa jadi membingungkan terkait dengan mekanisme praktik layanan dan penyelenggaraannya, namun walau demikian program home visit memiliki model program dan materi yang jelas. Selanjutnya Daro, Sweet dan Appelbaum dalam Korfmacher (2008) melakukan pemetaan program home visit, terdiri dari materi program, populasi, filosofi, staf dan kurikulum. Berdasarkan sejumlah tinjauan dan laporan meta analisis, program home visit menghasilkan keluaran layanan home visit PAUD yang positif.

Terdapat beberapa definisi mengenai home visit dalam bidang pendidikan anak usia dini. Scoot dan McDonald (2002) mengungkapkan bahwa:

"The home visiting programs combine delivery of services to children, caregivers, and communities by providing stimulation and play activities, education and support of parents, promotion and organization of community involvement, and referral to agencies that offer educational, health care, economic, and other oppotunities and support for children and adults. "

Program home visit merupakan program yang memadukan berbagai pelayanan untuk anak-anak, pengasuh, dan masyarakat. Dalam praktiknya, layanan home visit memberikan stimulasi dan beragam aktivitas bermain untuk anak- anak, pendidikan dan dukungan orang tua serta meningkatkan keterlibatan masyarakat. Selain itu program home visit merujuk pada lembaga pendidikan, kesehatan, kesejahteraan sosial dan lembaga yang memberikan peluang dan dukungan unruk perkembangan anak dan orang dewasa.

Drummond, Weir dan Kysela (2002) mengungkapkan bahwa program home visit merupakan program pendekatan yang dilakukan untuk memenuhi kebutuhan bayi dan anak-anak pra-sekolah yang hidup dalam kondisi beresiko. Dalam Convention on The Rights of The Child (CRC) survival, protection and development, terdapat tiga rumusan model layanan home visit PAUD, sebagai berikut:

1. Roving caregivers program adalah layanan untuk memenuhi kebutuhan anak dari ibu muda dan keluarga miskin,

2. Community based rehabilitation program, layanan untuk membantu anak-anak berkebutuhan khusus

3. Malnourished children's program, layanan yang ditujukan kepada kebutuhan nutrisi dan psikososial.

Menurut Portage dalam Roopnarine dan Johnson (2009), Program home visit memiliki tahapan-tahapan yang terdiri dari tiga tahapan, yaitu:

1. Intervensi langsung

Tahap ini berfokus pada kemajuan perkembangan bayi atau anak, tinjauan dan demonstrasi kegiatan yang akan dilakukan di rumah, praktik dan demonstrasi ulang oleh orangtua, dan diskusi mengenai tujuan dan hasil yang diharapkan dari semua tugas (yang disebut sebagai proses pengajaran rumah).

2. Interaksi dan permainan informal Pada tahapan ini, petugas home visit memberikan informasi penilaian, kurikulum yang penting dan rencana kegiatan permainan informal serta mem- 
bimbing ibu untuk membantu bayi atau anak dalam proses generalisasi dan mempertahankan kegiatan yang dipelajari dengan mempertahankan kegiatan yang dipelajari dengan memasukannya ke dalam rutinitas harian.

3. Upaya dukungan keluarga

Pada tahap ini, petugas home visit berperan sebagai pendengar bagi sang ibu, memberikan informasi dan bantuan yang tepat dan diminta oleh keluarga, dan memperoleh kepercayaan serta hubungan baik dengan keluarga.

Selanjutnya, Kerida Scott dan McDonald (2002) memaparkan dua belas elemen dalam program home visit, sebagai berikut:

1. Hubungan antara dukungan perawatan anak dan dukungan keluarga

2. Pengakuan atas peran ganda wanita sebagai ibu, ibu rumah tangga dan ibu bekerja

3. Transfer keterampilan pada anggota keluarga/ rumah tangga

4. Fleksibilitas dalam layanan

5. Pengakuan atas konfigurasi keluarga dan membangun jaringan yang ada untuk anak-anak

6. Keberlanjutan materi program bermain

7. Rujukan sistem dan dukungan akses yang kuat

8. Retensi staff yang tinggi

9. Dokumentasi

10. Mekanisme monitoring dan umpan balik yang kuat

11. Orientasi penelitian mengarah pada tindakan

12. Pengukuran proaktif untuk menentukan keberlanjutan dan institusionalisasi

\section{Studi Layanan Home Visit Paud di Negara Bagian Amerika}

Negara Amerika memiliki komitmen yang besar terhadap pendidikan dan perkembangan anak usia dini. Program home visit dalam bidang pendidikan dan perkembangan anak usia dini menjadi salah satu agenda Presiden Barack Obama. Kemunculan program home visit di Amerika diawali oleh Head Start, sebuah program pendidikan anak usia dini federal terbesar di Amerika Serikat.

Program-program Head Start merupakan program yang mengarah pada pembinaan keluarga dan anak-anak yang masih sangat kecil dari keluarga miskin, serta memberikan program intervensi pendidikan untuk anak-anak dan pendidikan pada orangtua dengan didasari atas pemahaman bahwa keluarga memiliki peranan yang sangat penting dalam meningkatkan perkembangan anak. Head Start memberikan pelayanan pada keluarga-keluarga di Amerika untuk mendukung peran keluarga sebagai orang tua dan guru pertama bagi anak, memberikan pelatihan dan mendukung para orangtua untuk mengambil peran sebagai pemimpin dalam program home visit dan dalam pendidikan untuk anak-anak mereka.

Saat ini, program home visit pendidikan anak usia dini merupakan program yang berada di bawah departemen The Affordable Care Act. Departemen tersebut menyediakan dana $\$ 1,5$ triliyun per 5 tahun untuk program Home visit PAUD di wilayah-wilayah bagian Amerika dengan kondisi penduduk yang rentan kemiskinan. Program home visit di Amerika meliputi program kesehatan, pendidikan dan intervensi dini yang diharapkan dapat meningkatkan kesehatan dan perkembangan anak dan menyiapkan anak-anak untuk bersekolah dan menghadapi kehidupan yang lebih baik di masa yang akan datang.

Pada tahun 2013, Presiden Barack Obama melanjutkan pendanaan untuk setiap periode sepuluh tahun yang ditujukan untuk program Home visit PAUD. Hal ini disebabkan atas dasar keyakinan bahwa program Home visit PAUD merupakan program yang sangat 
penting dalam meningkatkan kesehatan ibu dan anak pada tahun-tahun pertama kehidupan anak, dapat memberikan pengaruh positif terhadap keterampilan pengasuhan orang tua, serta dapat mengembangkan aspek kognitifm bahasa, sosial-emosional dan kesiapan sekolah anak. Melalui ini pemerintah Amerika berupaya untuk membantu masyarakat Amerika yang hidup dalam kemiskinan untuk dapat memulai hidup yang lebih baik, dimulai dari pendidikan anak sejak lahir yang akan menjadi investasi masa depan.

\section{Praktik Layanan Home Visit PAUD dalam Meningkatkan Pertumbuhan dan Perkembangan Anak Usia Dini pada Keluarga Kurang Sejahtera}

Program home visit PAUD merupakan sebuah program yang memberikan layanan berupa pendidikan orangtua, pendidikan dan perkembangan anak serta dukungan layanan terhadap anak-anak dan keluarga kurang sejahtera. Program home visit memiliki beragam bentuk dan ukuran, menurut Kimberly S. Howard and Jeanne Brooks-Gunn (2009) hal ini dikarenakan program home visit tidak hanya menggunakan pendekatan teoritis, namun juga dapat menggunakan pendekatan praktis.

Pendekatan praktis dalam program home visit terkait dengan pelaksanaan program individual, dalam program ini dirancang kegiatan kunjungan rumah berdasarkan pada isi kurikulum program. Kurikulum program terdiri dari program pengasuhan, pendidikan dan perawatan. Ratzlaff, Fulton, Katz, dkk pada tahun 2011 melakukan penelitian yang berkaitan dengan program home visit, hasil penelitian menunjukan bahwa program home visit mampu meningkatkan pemahaman orangtua mengenai perkembangan anak, mengurangi kesalahan penanganan pada bayi, meningkatkan kualitas lingkungan dimana anak tinggal. Berikut adalah tabel yang menggambarkan kegiatan home visit PAUD yang diadopsi dari model home visit Portage (Roopnaire \& Johnson, 2009):

\begin{tabular}{|c|c|c|}
\hline $\begin{array}{l}\text { Kegiatan Intervensi } \\
\text { Langsung }\end{array}$ & $\begin{array}{l}\text { Kegiatan Informal } \\
\text { 30-35 Menit }\end{array}$ & $\begin{array}{c}\text { Kegiatan Orangtua dan } \\
\text { Keluarga } \\
\text { 20-30 Menit }\end{array}$ \\
\hline $\begin{array}{l}\text { Siapa: } \\
\text { Orang tua, petugas kun- } \\
\text { jungan rumah, dan anak }\end{array}$ & $\begin{array}{l}\text { Siapa: } \\
\text { Orangtua, anak, saudara, } \\
\text { petugas kunjungan rumah }\end{array}$ & $\begin{array}{l}\text { Siapa: } \\
\text { Orangtua, petugas kunjung- } \\
\text { an rumah }\end{array}$ \\
\hline $\begin{array}{l}\text { Apa: } \\
\text { Kegiatan ditujukan pada } \\
\text { penguasaan keterampilan } \\
\text { khusus dalam semua area } \\
\text { komponen: } \\
\text { Tinjauan } \\
\text { Demonstrasi } \\
\text { Praktik } \\
\text { Diskusi }\end{array}$ & $\begin{array}{l}\text { Apa: } \\
\text { Kegiatan untuk membantu } \\
\text { ekspresi kreatif anak, ke- } \\
\text { sempatan bagi pengajaran } \\
\text { spontan dan perluasan ke- } \\
\text { terampilan melalui: } \\
\text { Pemeliharaan } \\
\text { Generalisasi } \\
\text { Penggabungan ke dalam } \\
\text { rutinitas harian }\end{array}$ & $\begin{array}{l}\text { Apa: } \\
\text { Orang tua dan petugas kun- } \\
\text { jungan rumah bekerjasama } \\
\text { dalam: } \\
\text { menentukan kebutuhan } \\
\text { memperluas dasar penge- } \\
\text { tahuan orang tua } \\
\text { menguatkan kemampuan } \\
\text { memecahkan masalah }\end{array}$ \\
\hline $\begin{array}{l}\text { Bagaimana: } \\
\text { Proses pengajaran di ru- } \\
\text { mah terdiri dari: } \\
\text { petugas kunjungan rumah } \\
\text { menunjukan kegiatan baru } \\
\text { dan mencatat titik dasar }\end{array}$ & $\begin{array}{l}\text { Bagaimana: } \\
\text { Melalui kegiatan sepeti ke- } \\
\text { senian, musik, berjalan- } \\
\text { jalan di alam bebas, waktu } \\
\text { makan, waktu mandi dan } \\
\text { lain-lain. }\end{array}$ & $\begin{array}{l}\text { Bagaimana: } \\
\text { Ini dicapai dengan: } \\
\text { merencanakan kegiatan ku- } \\
\text { rikulum mingguan } \\
\text { berbagai informasi yang di- } \\
\text { perlukan mengembangkan }\end{array}$ \\
\hline
\end{tabular}




\begin{tabular}{ll}
\hline petugas kunjungan rumah & strategi untuk mengatasi \\
mendapatkan titik dasar & kekhwatiran keluarga \\
Orangtua mencotohkan ke- & \\
giatan baru & \\
orangtua dan petugas kun- & \\
jungan rumah meninjau & \\
kegiatan dan mencatat & \\
\hline
\end{tabular}

\section{Pendidikan dan Pengembangan Anak Usia Dini di Indonesia}

Perkembangan pendidikan anak usia dini dalam satu dekade terakhir memperlihatkan kemajuan yang pesat. Pada tahun 2001, pemerintah Indonesia mulai mengambil langkah membentuk direktorat baru di bawah Kementerian Pendidikan dan Kebudayaan, yaitu Direktorat Pendidikan Anak Usia Dini yang didedikasikan untuk pendidikan dan pengembangan anak usia dini. Selanjutnya pada tahun 2003, pemerintah memasukan pendidikan dan pengembangan anak usia dini ke dalam Undang-Undang RI Nomor 20 Tahun 2003 tentang Sistem Pendidikan Nasional, dinyatakan bahwa pendidikan anak usia dini adalah suatu upaya yang ditujukan bagi anak sejak lahir sampai dengan usia enam tahun yang dilakukan melalui pemberian ransangan pendidikan untuk membantu pertumbuhan dan perkembangan jasmani dan rohani agar anak memiliki kesiapan dalam memasuki lebih lanjut.

Pada Pasal 28 tentang pendidikan anak usia dini dikemukakan bahwa sistem penyelenggaraan pendidikan anak usia dini terbagi ke dalam berberapa jalur, yaitu:

1. Jalur pendidikan formal berbentuk Taman Kanak-Kanak (TK)/Raudhatul Atfal (RA) dan bentuk lain yang sederajat, pro

2. Jalur pendidikan nonformal berbentuk Taman Penitipan Anak (TPA) dan bentuk lain yang sederajat, program ditujukan untuk anak usia $0-<2$ tahun, $2-<4$ tahun, 4- 6 tahun dan Program Pengasuhan untuk anak usia
0 - =6 tahun; Kelompok Bermain (KB) dan bentuk lain yang sederajat, menggunakan program untuk anak usia $2-<4$ tahun dan $4-=6$ tahun.

3. Jalur pendidikan informal, berupa pendidikan keluarga atau pendidikan yang diselenggarakan oleh lingkungan.

Menyahuti Undang-Undang tersebut dalam implementasinya pemerintah telah melaksanakan sebuah gerakan untuk meningkatkan kualitas pendidikan dan perkembangan anak usia dini yang terus bergulir hingga kini, pada tahun 2006 pemerintah melakukan revitalisasi posyandu menjadi layanan yang memadukan kesehatan dan pendidikan. Selanjutnya pada tahun 2008, dirancang strategi kebijakan nasional mengenai pendidikan dan pengembangan anak usia dini holistik integratif. Tahun 2009, pemerintah menetapkan standar nasional pendidikan anak usia dini melalui Peraturan Menteri nomor 58.

Dengan berbagai inisiasi yang dilakukan oleh pemerintah mengenai pendidikan anak usia dini, hal tersebut memberikan dampak yang cukup besar dalam meningkatkan kesadaran masyarakat akan pendidikan anak usia dini dan beragam program pendidikan anak usia dini yang digulirkan oleh pemerintah mampu meningkatkan angka partisipasi anak dalam mengikuti program pendidikan anak usia dini walaupun masih terdapat kesenjangan dan hambatan dalam pemerataan akses layanan pendidikan anak usia dini di berbagai daerah. 


\section{Pemetaan Layanan Home Visit PAUD di Indonesia}

Negara Indonesia berada di posisi keempat sebagai negara dengan jumlah penduduk terpadat di dunia yang berjumlah lebih dari 238 juta jiwa yang tersebar di 17.000 pulau. Di antara jumlah penduduk tersebut, populasi anakanak sebanyak 31.8 juta jiwa dan 56,3\% diantaranya hidup di wilayah terpencil sedangkan sebanyak $57,1 \%$ hidup di pulau jawa. (CBS dalam laporan Bank Dunia, 2012). Berdasarkan data ini menggambarkan bahwa Indonesia masih mengalami kesenjangan dalam hal angka partisipasi dalam program pendidikan dan pengembangan anak usia dini, kemungkinan anak-anak kurang sejahtera untuk berpartisipasi tetap jauh lebih kecil. Seperti terlihat pada grafik di bawah ini.

\section{Grafik 1.}

Kesenjangan Partisipasi PAUD Berdasarkan Tingkat Kesejahteraan Keluarga

Sumber: Susenas, 2004, 2007,2010

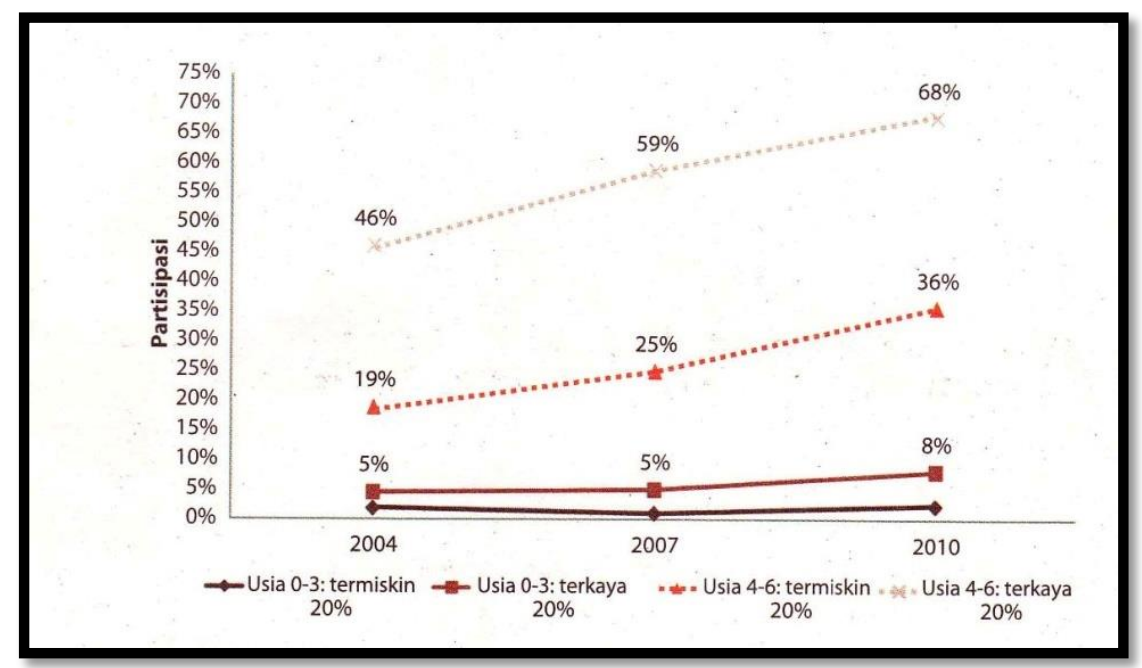

Permasalahan kesenjangan partisipasi pada anak-anak kurang sejahtera dan sejahtera menjadi sebuah permasalahan dan tantangan tersendiri. Lydia Freyani Hawadi dalam International Conference of Early Childhood Education and Development (2012) mengungkapkan bahwa negara Indonesia memiliki beragam permasalahan dan tantangan dalam bidang pendidikan anak usia dini, diantaranya:

1. Akses layanan pendidikan anak usia dini belum merata di berbagai wilayah terutama di daerah pedesaan, tertinggal, terisolir dan terdepan

2. Rendahnya, angka partisipasi kasar (APK) pendidikan anak usia dini, APK terendah pada rentang usia 0-2 tahun,
3. Orangtua yang memiliki anak usia 02 tahun membutuhkan bantuan dalam pendidikan dan pengembangan anak,

4. Rendahnya kualitas layanan PAUD untuk anak usia 3-6 tahun

5. Sebanyak 3.298.428 (40,5\%) anak usia 5-6 tahun telah mengikuti pendidikan SD/MI,

6. Rendahnya kontribusi masyarakat dalam mendukung pembiayaan PAUD.

7. Rendahnya kemampuan pendidik anak usia dini

Beragam permasalahan dan tantangan di atas tidak hanya menjadi tanggung jawab pemerintah, masyarakat memiliki andil dalam meningkatkan kualitas pendidikan anak usia dini. Dalam hal rendahnya APK PAUD pada 
rentang usia 0-2 tahun dan kebutuhan orang tua akan bantuan mengenai pendidikan dan pengembangan anak usia 0-2 tahun, pemerintah telah merancang strategi untuk membantu para orang tua dalam memberikan pendidikan, pengasuhan dan perawatan yang layak untuk usia 0-2 tahun. Beberapa strategi yang telah dirancang adalah dengan melakukan kerjasama dengan Tim Penggerak Kesejahteraan keluarga (PKK), Kementerian Kesehatan dan Badan Koordinasi keluarga Berencana Nasional (BKKBN), bentuk kerjasamanya adalah dengan mengintensifkan layanan Pos PAUDberbasis layananPosyandu dan Bina Keluarga Balita disetiap desauntuk menjangkausasaran usia 0-2 tahun, selain itu, pemerintah juga merancang program pendidikan orang tua (parenting).

Namun strategi yang telah dirancang nyatanya belum dapat terlaksana dengan optimal, hal ini disebabkan tingkat kesadaran orang tua mengenai pentingnya intervensi dan pendidikan anak usia dini yang masih rendah, selain itu kurangnya pengetahuan dan keterampilan Tim Penggerak PKK mengenai perkembangan anak usia dini membuat layanan Pos PAUD berbasis layanan Posyandu dan Bina Keluarga Balita tidak berjalan sesuai harapan, dalam pelaksanaannya program pendidikan dan kesehatan belum diberikan secara terpadu pada anak usia 0-2 tahun. Anak-anak yang berpartisipasi dalam program tersebut hanya mendapatkan layanan kesehatan, seperti penimbangan berat badan dan pemberian vitamin serta vaksinasi.

Oleh karena itu, diperlukan sebuah strategi baru dalam penanganan pendidikan dan pengembangan yang ditujukan untuk anak usia 0-3 tahun. Menilik keberhasilan program layanan home visit pendidikan anak usia dini di berbagai negara bagian Amerika, bagaimana peluang dan tantangan pelaksanaannya di Indonesia, dapatkan layanan home visit pendidikan anak usia dini diselenggarakan di wilayah Indonesia?

Dengan adanya dukungan dan strategi pemerintah dalam gerakan paud, negara Indonesia sudah memiliki potensi untuk penyelenggaraan layanan home visit. Adanya keterlibatan dan kerjasama antara departemen pendidikan, petugas PKK, departemen kesehatan dan departemen kesejahteraan keluarga, kerjasama tersebut sudah menjadi modal yang kuat untuk menyelenggarakan layanan home visit pendidikan anak usia dini.Kebijakan pemerintah dalam mengintegrasikan program pendidikan anak usia dini secara holistik integratif yang melibatkan berbagai departemen tentunya dapat menjadi langkah awal dalam perencanaan dan perumusan program layanan home visit pendidikan anak usia dini yang sesuai dengan kondisi dan kebutuhan keluarga dan anak di setiap wilayah Indonesia.

Penyelenggaraan program layanan home visit pendidikan anak usia dini diharapkan dapat memfasilitasi anakanak usia 0-3 tahun yang belum mendapatkan layanan paud agar dapat tumbuh dan berkembang dengan optimal melalui peran dan dukungan orang tua sebagai pendidik utama untuk anak di rumah. Selain itu program layanan home visit pendidikan anak usia dini juga diharapkan dapat memperluas dan meratakan akses pendidikan anak usia dini untuk seluruh anak Indonesia dari berbagai latar belakang sosial, ekonomi dan budaya.

\section{PENUTUP}

Tulisan ini telah mengkaji program home visit pendidikan anak usia dini dan tingkat keberhasilannya pada beberapa negara dalam memenuhi kebutuhan perkembangan anak-anak yang hidup dalam keluarga kurang sejahtera. Atas dasar analisis ini telah dipetakan bagaimana tantangan dan peluang dalam 
perencanaan implementasi penyelenggaraan layanan Home visit PAUD di wilayah Indonesia.

Dengan alternatif layanan Home visit PAUD sebagai program baru di Indonesia, diharapkan terjadinya penurunan tingkat kesenjangan partisipasi anak pada keluarga sejahtera dan keluar-

\section{DAFTAR RUJUKAN}

Bank Dunia. 2012. Pendidikan dan Pengembangan Anak Usia Dini di Indonesia: Landasan pokok, Masa Depan Cerah. Laporan Awal. Jakarta: Kantor Bank Dunia Jakarta

Drummond, J.E., Weir, A.E \& Kysela, G.M. 2002. Home Visitation Program for At-risk Young Family. Canadian Journal of Public Health; Mar/Apr 2002; 93, 2; ProQuest pg. 153

Howard, K.S, \& Gunn, J.B. 2009. The Role of Home-Visiting Programs in Preventing Child Abuse and Neglect. Fall 2009; Vol.19 No.2

Hawadi, Lydia F. 2012. Indonesia's Support to Children's Holistic Learning and Development. International Conference of Early Childhood Education and Development; November 05, 2012

Korfmacher, J, dkk. 2008. Parent Involvement in Early Childhood Home Visiting. Springer; May 2008; Child Youth Care Forum pg.171-196

Ratzlaff, A.H. \& Fulton, A. 2001. Knowledge Gained by Mothers Enrolled in a Home Visitation ga kurang sejahtera dalam mengikuti program PAUD. Selain itu, melalui program ini diharapkan dapat memperluas akses dan kualitas pendidikan anak usia dini sehingga anak-anak Indonesia terpenuhi kebutuhan perkembangannya dan dapat tumbuh serta berkembang menjadi generasi emas.

Program. Fall 2001; 36, 143; ProQuest pg. 435

Roopnarine \& Johnson. 2009. Pendidikan Anak Usia Dini dalam Berbagai Pendekatan. Jakarta: Kencana Prenada Media Group

Salinan Peraturan Menteri Pendidikan Nasional RI Nomor 58 Tahun 2009 Tentang Standar Pendidikan Anak Usia Dini

Santrock, John W. 1995. Perkembangan Masa Hidup. Jakarta: Penerbit Erlangga

Scott, K \& McDonald. 2002. Elements of Quality in Home Visiting Programs: Three Jamaican Models. Washington, D.C.: The World Bank

Sujono, Yuliani. 2011. Konsep Dasar Pendidikan Anak Usia Dini. Jakarta: Indeks

Young, Mary E. 2002. Ensuring a Fair Start for All Children: The Case of Brazil. Washington D.C.: The Word Bank

The White House Secretary. 2013. Fact Sheet President Obama's Plan for Early Education for all Americans. Diakses 04 November 2013, dari http://www.whitehouse.gov/issues/ education/early-childhood 